\title{
The Perspectives and Values of Children with a Mitochondrial Disorder with Regard to Everyday Activities
}

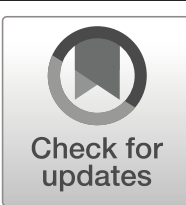

\author{
Marieke Lindenschot ${ }^{1,2,3,4}$ (D) Esther M. J. Steultjens $^{2,3}$ (D) Jana Zajec ${ }^{4}$ (D) \\ Maria W. G. Nijhuis-van der Sanden ${ }^{1,4}$ (D) Saskia Koene $^{5}$ (D) \\ Imelda J. M. de Groot ${ }^{4}$ iD
}

Published online: 15 October 2019

(C) The Author(s) 2019

\begin{abstract}
Engagement for children with mitochondrial disorder is not self evident. To develop personalised and value-based care for this population, we require knowledge about their perspectives and values with regards to everyday activities. To gain insight into children's perspective on activities by (1) asking what activities they perform, (2) how they perform them, (3) how they experience these activities and (4) their wants and needs. Seven semistructured content analyzed interviews. The interviews identified a variety of activities. The overarching themes on wants/needs were 'I want to meet up with others whenever I want to', 'I want to be able to...', 'I don't want to...' and 'Dream'. These themes were interconnected to thirteen other themes that captured how children experience and perform activities, for example, 'Because I can decide by myself', 'Because I can do it on my own' and 'It is more fun to do things with other people'. The activities children performed represent regular childhood activities. The identified themes fit with the three aspects of the self-determination theory: autonomy, competence and relatedness. This study exposed
\end{abstract}

\section{Marieke Lindenschot}

marieke.lindenschot@radboudumc.nl; marieke.lindenschot@han.nl

Esther M. J. Steultjens

esther.steultjens@han.nl

Jana Zajec

jana.zajec@ radboudumc.nl

Maria W. G. Nijhuis-van der Sanden

ria.nijhuis-vandersanden@ radboudumc.nl

Saskia Koene

saskia.koene@ radboudumc.nl

Imelda J. M. de Groot

imelda.degroot@radboudumc.nl

Extended author information available on the last page of the article 
the broad child perspective and should provide better understanding of children's choices in their participation in everyday activities.

Keywords Children · Mitochondrial disease - Disabilities · Activities of daily living · Meaning

\section{Introduction}

Performing everyday activities is a basic human need (Law et al. 2005), a key element for wellbeing and an important determinant of health for children of all ages (Asbjornslett and Hemmingsson 2008; Bendixen and Kreider 2011; Law et al. 2005). Performing activities is the most important part of participation (Eriksson and Granlund 2004). Although the type of activities depends on age, a logical consequence of cognitive development (Piaget 1964), and psychosocial development (Erikson 1993), concepts of participation do not appear age-related (Eriksson and Granlund 2004). Unfortunately, engagement in age-related activities is not selfevident for children with a disability, and this fact can negatively influence participation (Heah et al. 2007; Shields et al. 2014). Children with mitochondrial disorders, rare diseases that affect cellular energy metabolism, experience limitations in their physical and cognitive capacities; these deficiencies range from very small to extremely high (Koene et al. 2013). Mitochondrial disorders are one of the most common inherited metabolism disorders and have an estimated prevalence of 23 in 100,000 (Gorman et al. 2015). These inherited metabolism errors can be caused by mutation of genes encoded by mitochondrial DNA (mtDNA) or nuclear DNA (nDNA) ((Koopman et al. 2012). The number of identified genes associated with a mitochondrial disorder continuously increases. Mutations in more than 350 genes of both mitochondrial and nuclear origin have already been identified (Rahman and Rahman 2018). This genetic heterogeneity is also reflected in the wide range of symptoms and impairments associated with mitochondrial disorders, from motor to cognitive impairments (Dassler and Allen 2014; Kisler et al. 2010; Koene and Smeitink 2009; Koene et al. 2013). The most prevalent symptoms in children with mitochondrial disorders are developmental delay, intellectual problems, speech and language impediments and physical disabilities, including muscle weakness, coordination problems and/or balance problems (Koene et al. 2013). Parents also mention that in addition to a lack of energy, developmental and physical disabilities greatly impact daily functioning (Koene et al. 2013). Therefore, children with mitochondrial disorders are vulnerable in their participation and performance of everyday activities.

The impact of the disabilities on everyday activities is illustrated by a study by Martens et al. (2014), who found that children with mitochondrial disorders are less physically active and engaged in vigorous activities compared to healthy peers. Furthermore, the activity level of children with mitochondrial disorders as measured with an accelerometer varies from nearly normal to severely impaired (de Vries et al. 2019). The most burdensome complaints on the levels of activity and participation, reported by children and their parents, are learning to write and calculate and engaging in activities at school, around the neighbourhood and in the community (Koene et al. 2013). However, a recent exploratory qualitative study indicates that the mitochondrial disorder does not impact the categories of activities the children perform compared to healthy peers. Indeed, these subjects perform self-care-, therapy-, school-, computing-, hobby-, play-, sports- and mobility/transport-related activities and house chores. Instead, the impact is noticeable in how these children perform the activities; evidence suggests 
differences in the level of independence, assistive device usage and energy costs compared to healthy peers (Lindenschot et al. 2018). Still, since this study was a retrospective chart review, it remains unclear whether the activities the children performed represent what they themselves prefer. Knowledge about the type of activities children perform and prefer, as well as how they perform these activities, is important to be able to provide tailored occupation-based care. However, there is a scarcity of literature on the impact of mitochondrial disorders on everyday activities, and most importantly, the perspective of the child is underexplored in these studies.

The perspective of the individual on their everyday life is critical, because personalised and value-based care is an important factor in paediatric health care (Coyne et al. 2016). To achieve value-based care, we need to know how children value their activities. Previous literature that studied the perspective of children on their everyday life activities focused specifically on leisure or play and not on everyday activities, even though children want to participate in all parts of everyday life (Costa et al. 2017). For example, Powrie et al. (2015) conducted a systematic evidence synthesis of the meaning of leisure for children and young people with physical disabilities. They identified four themes that represent the meaning of leisure: fun, freedom, fulfilment and friendship. Graham et al. (2018) used systemic thematic synthesis to evaluate the meaning of play for children and young people with physical disabilities. They identified several analytical themes: play can feel both positive and negative, play can draw attention towards or away from my disability, play is a social interaction, I participate differently from my peers and needing help feels normal. These findings are probably not transferrable to other areas of daily life like self-care or productivity. Besides, these studies focused on children with physical disabilities. Moreover, literature that does include children with multiple disabilities often uses parents as an input for their results. For example, the review of Willis et al. (2017) provides a good overview on elements that contribute to meaningful participation: person-based elements (having fun, experiencing success, belonging, experiencing freedom, developing an identity), environment-focused elements (authentic friendships, the opportunity to participate, role models, family support) and activity-related element (learning). Unfortunately, they included more literature about children with physical disabilities than children with multiple disabilities. They also included studies from both the children's and parents' perspectives. While Costa et al. (2017) mentioned that parents' main concerns are related to school task performance, children assign priority to their independence, competence and joy in meaningful everyday activities. Nonetheless, we are aware of one study that focused on participation concepts in children and adults with multiple disabilities (Eriksson and Granlund 2004) that may be comparable to our study population. They found nine themes related to how the subjects experience participation: characteristics/self-esteem, fellowship, communication, being a part of activities, self-determination, prerequisites for taking part in activities, the role of the adult, conditions in the living environment and physical environment. However, this study focused on participation as a total concept and not on the experience of singular everyday activities. Further, they only examined the special education context, and the sample also included 19 adults out of 334 participants. Hence, the individual perspective of the child with multiple disabilities, such as children with mitochondrial disorders, on everyday activities is still underexplored. This perspective can be used in clinical practice to establish occupation based, value-based and personalised care.

Therefore, the aim of this study was to gain insight into the perspectives and values of children with mitochondrial disorders on their everyday activities. To achieve this aim, we asked children what activities they perform, how they perform and experience these activities and what their wants and needs are. 


\section{Methods}

A qualitative study, using semi-structured interviews, was conducted. Content analysis (Hsieh and Shannon 2005) was used to allow themes to emerge from the data. Purposeful sampling was used to include 2-to-18-year-old children with a mitochondrial disorder with different functioning profiles (Lindenschot et al. 2018).

\section{Participants and Recruitment}

Children with a genetically confirmed mitochondrial disorder, who are periodically evaluated at the Radboud University Medical Centre (Radboudumc) Nijmegen, were eligible to participate in the study. Criteria used for consideration were age and current involvement in other studies (to prevent too much of a burden on the children). No exclusion criteria considering physical, cognitive and communication (dis)abilities were formulated. Children who were not involved in other studies were contacted $(n=13)$. The patient information letter was sent to these children and their parents by the medical doctor who considered the children for eligibility; she also asked parents if the researcher could contact them. After two weeks, they were contacted by the researcher, who provided additional information and asked parents if they and their child were willing and able to participate. The interview was scheduled at a location chosen by the child and his/her parents: at home or the Radboudumc.

Four children declined participation due to recent participation in other research, disagreement between parents, school business and/or potential burdens on the family. Nine children and their parents provided informed consent and participated in the study; demographics are given in Table 1. Since mitochondrial disorders are rare and we chose to recruit from only one centre, we did not expect a larger sample size to be realistic.

Eight children were native Dutch speakers and one was a native German speaker. Participants varied in the type of genetic defect (Table 2), age, gender and functional capacities (see Table 1). For privacy reasons, the mutations listed in Table 2 and not connected to the data in Table 1 to prevent potential recognition. Six children have a mutation in nDNA, three children in mtDNA. The functional capacities were extracted from patient files. In two cases, more clinically relevant priorities hindered scheduling of the fatigue assessment during the clinical visit, and thus it was not available in the chart. To provide insight into the functional capacities of the children, we used the following three profiles, based on previous research (Lindenschot et al. 2018):

- Global low functioning: children with an extremely low or low cognitive developmental level and limited in their motor functioning, both of which lead to nonfunctional outdoors ambulation and non-functional communication;

- Low cognitive functioning with moderate-to-normal ambulation: children with an extremely low or low cognitive developmental level, some limitations in motor functioning but capable of functional ambulation. Speech abilities in this profile differ among the children;

- Global moderate functioning: children with an average cognitive developmental level, some limitations in motor functioning but capable of functional ambulation. Speech abilities are sufficient to make themselves understood. 
Table 1 Clinical characteristics of the children who participated in this study

\begin{tabular}{|c|c|c|c|c|c|c|c|c|}
\hline Gender $^{\mathrm{a}}$ & $\mathrm{Age}^{\mathrm{b}}$ & $\begin{array}{c}\text { Level of } \\
\text { cognitive } \\
\text { develop- } \\
\text { ment }^{\mathrm{c}}\end{array}$ & $\begin{array}{l}\text { Level of } \\
\text { motor } \\
\text { develop- } \\
\text { ment }^{\mathrm{d}}\end{array}$ & $\underset{\mathrm{e}}{\text { Ambulation }}$ & $\begin{array}{l}\text { Level of } \\
\text { speech } \\
\text { ability }^{f}\end{array}$ & $\begin{array}{c}\text { Level of } \\
\text { functional } \\
\text { abilities in } \\
\text { daily } \\
\text { activities }\end{array}$ & $\begin{array}{l}\text { Fatigue } \\
\text { score }^{\mathrm{h}}\end{array}$ & $\begin{array}{c}\text { Interview } \\
\text { techniques } \\
\text { successful? }\end{array}$ \\
\hline \multicolumn{9}{|c|}{ Global low functioning $(\mathrm{N}=3)$} \\
\hline $\mathrm{F}$ & $\mathrm{S}$ & 1 & 2 & 1 & 4 & 2 & 71 & $\mathrm{Y}$ \\
\hline $\mathrm{M}$ & $\mathrm{S}$ & 1 & 2 & 2 & 3 & 2 & 49 & $\mathrm{Y}$ \\
\hline $\mathrm{M}$ & $\mathrm{S}$ & 1 & 3 & 1 & 1 & 1 & NA & $\mathrm{N}$ \\
\hline \multicolumn{9}{|c|}{ Low cognitive functioning and moderate-to-normal ambulation $(\mathrm{N}=3)$} \\
\hline $\mathrm{F}$ & $\mathrm{A}$ & 2 & 3 & 5 & 5 & 4 & NA & $\bar{Y}$ \\
\hline $\mathrm{M}$ & $\mathrm{A}$ & 1 & 3 & 4 & 2 & 3 & 32 & $\bar{Y}$ \\
\hline $\mathrm{M}$ & $\mathrm{S}$ & 1 & 3 & 5 & 3 & 2 & 49 & $\mathrm{~N}$ \\
\hline \multicolumn{9}{|c|}{ Global moderate functioning $(\mathrm{N}=3)$} \\
\hline $\mathrm{F}$ & $\mathrm{S}$ & 3 & 3 & 4 & 6 & 3 & 72 & $\mathrm{Y}$ \\
\hline $\mathrm{M}$ & $\mathrm{S}$ & 3 & 2 & 4 & 6 & 3 & 66 & $\mathrm{Y}$ \\
\hline $\mathrm{M}$ & $\mathrm{S}$ & 3 & 4 & 4 & 6 & 3 & 38 & $\mathrm{Y}$ \\
\hline Total $(\mathrm{N}=9$ & & & & & & & & \\
\hline
\end{tabular}

a: $\mathrm{M}=$ male; $\mathrm{F}=$ Female; b: $\mathrm{S}$ : school age (4-12 years), A: adolescent age (13-18 years); c: based on agerelated norm-referenced test-1: extremely low, 2: low, 3: average, 4: good; d: based on age-related normreferenced test-1: spasticity, 2: ataxia, 3: extremely delayed, 4: delayed, 5: normal development; e: based on Hoffer scale-1: non-ambulation, 2: non-functional ambulation, 3: household ambulation, 4: community ambulation, 5: normal ambulation; f: based on Radboud dysarthria assessment-1: no oral communication possible, 2: communication with a known person, 3: frequent repetitions, 4: incidental repetitions, 5: effective despite small problems, 6: effective communication; g: based on Pediatric Evaluation of Disability Inventory (PEDI) - 1: not self-independent, 2: minimal self-independent, 3: sufficient self-independent, 4: fully selfindependent; h: measured with the Pediatric Quality of Life Inventory Multidimensional Fatigue Scale (PedsQL-MFS); the higher the score, the better the (by fatigue impacted) health-related quality of life; NA: not addressed; i-Y: yes, interview successful in gaining child's perspective, N: interview not successful in gaining the child's perspective

All the children were living with their parents at home. All children in the global low functioning profile and two children in the low cognitive functioning and moderate to normal ambulation profile went to a special education school. The other four children went to regular education school.

Table 2 Genetic defects in the participating children

\begin{tabular}{lll}
\hline Number & Gene $^{\mathrm{a}}$ & Mutation \\
\hline 1 & ATP6 & $\mathrm{m} .09185 \mathrm{~T}>\mathrm{C}$ \\
1 & ATP6 & $\mathrm{m} .8993 \mathrm{~T}>\mathrm{G}$ \\
1 & mt-tRNASer & $\mathrm{m} .7507 \mathrm{~A}>\mathrm{G}$ \\
1 & MTFMT & $\mathrm{c} .626 \mathrm{C}>\mathrm{T} ; \mathrm{c} .766 \mathrm{C}>\mathrm{T}$ \\
1 & NDUFS1 & $\mathrm{c} .683 \mathrm{~T}>\mathrm{C} ; \mathrm{c} .737+3 \mathrm{~A}>\mathrm{G}$ \\
2 & NDUFS7 & $\mathrm{c} .364 \mathrm{G}>\mathrm{A}$ (homozygous) \\
1 & OPA1 & $\mathrm{c} .910 \mathrm{C}>\mathrm{T}$ (homozygous) \\
1 & SDHA & $\mathrm{c} .642 \mathrm{~A}>\mathrm{G}$ (homozygous) \\
\hline
\end{tabular}

a: $A T P 6=$ ATP synthase $6 ; m t-t R N A$ Ser $=$ mitochondrial tRNA serine; $M T F M T=$ mitochondrial methionyltRNA formyltransferase; NDUFS1 = NADH-ubiquinone oxidoreducase Fe-S protein 1 ; NDUFS7 = NADHubiquinone oxidoreducase Fe-S protein 7; OPA1 = optic atrophy 1; SDHA = succinate dehydrogenase complex, subunit A 
Table 3 Topic list for the interviews

Aim:

Gain insight into the children's perspectives on everyday activities: what do the children do, how do they perform the activities, how do they experience activities and what do they want to do?

\begin{tabular}{|c|c|}
\hline Topics & Aspects \\
\hline Daily Activities & $\begin{array}{l}\text { - Based on chart study: } \\
\text { - School activities } \\
\text { - Computing activities } \\
\text { - Hobby activities } \\
\text { - Play activities } \\
\text { - Sports activities } \\
\text { - Mobility/transport activities } \\
\text { - Self-care activities } \\
\text { - House chores } \\
\text { - Therapy activities }\end{array}$ \\
\hline Fun - not fun & $\begin{array}{l}\text { - Selecting fun activities } \\
\text { - Selecting activities that are not fun }\end{array}$ \\
\hline Experience activities & $\begin{array}{l}\text { - Why are the activities fun or not fun? } \\
\text { - What is the fun or not-fun part? } \\
\text { - Why do you do it? } \\
\text { - What is the importance? }\end{array}$ \\
\hline Ways of performance & $\begin{array}{l}\text { - With whom? } \\
\text { - Where? } \\
\text { - Support/devices/specific equipment? } \\
\text { - When are you satisified? }\end{array}$ \\
\hline Wants and needs & $\begin{array}{l}\text { - Wants and needs in general } \\
\text { - Activities you do not perform, but want to } \\
\text { - Why do you not perform these? } \\
\text { - Why do you want to? } \\
\text { - Activities you want to perform better } \\
\text { - Why do you want to do these better? } \\
\text { - What is the desired level of performance? }\end{array}$ \\
\hline
\end{tabular}

\section{Data Collection}

Semi-structured interviews were used to gain several perspectives from the children about their everyday activities. The perspectives were: (1) What do they do?; (2) How do they perform these activities?; (3) Why do they perform these activities; (4) What do they want to do (better)? All interviews were performed by the same researcher (ML) and conducted with the same topic list (see Table 3) and interview guide. The interviews were performed in Dutch, and the mother of the Germanspeaking child translated for her child. The researcher was a native Dutch speaker with intermediate competence of the German language. During the interview, different techniques were used to stimulate the child's responses and expressions. The interview techniques were adapted to the child's abilities and his/her communication preferences. The following techniques were integrated during the interview: 'standard' semi-structured questions, closed questions based on information from the mother, auto-driven photo elicitation, use of Talking Mats ${ }^{\circledR}$ picture 
symbols, questions during play, use of play (fantasy play) and use of a handpuppet. The interviewer/researcher is also a paediatric occupational therapist and is skilled in different interview techniques and communicating with children. The decision-making algorithm used for deciding on the interview technique started with knowledge about the global functioning profile. When this information was known before the interview (based on the previous retrospective chart study), the interview commenced with standard-semi structured questions for children with a global moderate functioning profile or with Talking mats ${ }^{\circledR}$ or auto-driven photos for the other two functioning profiles. However, for adolescent children, the interview began with standard semi-questions to avoid making her/him feel like the interview technique was childish. This last choice was made by the child and parent based on preferences. When the global functioning profile was not known, the researcher decided which technique to use based on her observations and professional reasoning during her introduction to the child. All interviews started with a 'try-out'; the chosen technique was used and judged as successful or unsuccessful. When it was not successful, it was adapted to the child by making it easier or more fun (in order to enhance communication). An in-depth description of the methods used and the decision-making algorithm is presented in Steultjens et al. (submitted). The utilised interview techniques, parental involvement and interview locations are presented in Table 4.

During the interviews, two children were not able to provide their own perspective on everyday activities due to cognitive limitations and communication difficulties. In one case, the child confabulated, and in the other case the child communicated through non-verbal signals (eye blinking and facial expressions), which were difficult to interpret without involving the mother. The interpretations were examined with the videotape, and it was unclear whether the researcher's interpretations were correct. Whereas the aim of this study was to gain insight into the child's perspective, these interviews were not analysed. As a result, only seven interviews were analysed. The two children whose interviews were not analysed are shaded in grey in Table 1.

After the interview, a summary of the children's activities and experiences was sent to the children and their parents. To enhance the interpretative rigour of the outcomes, parents were asked to check the summary and provide a reaction. Parents gave their written reaction if the summary was adequate or if information was incorrect or incomplete. This member check resulted in some small additions that contained the daily activities of the child. For example, a parent mentioned that the child also went to physical therapy, but this event was not mentioned during the interview. These additions were added to the transcript that was used for the analysis. No additions or corrections on the other topics were provided by the parents.

\section{Data Analysis}

The interviews were recorded on videotape, of which the audio was transcribed. Nonverbal responses (for instance, eagerness, happiness, eye-blinking, irritability or looking at parents), based on the video footage, were also added to the transcriptions. The Dutch-German interview was transcribed in Dutch by a bilingual person who is a native German speaker. 
Table 4 The utilised techniques, parental involvement and location for the interviews

\begin{tabular}{|c|c|c|c|}
\hline Case & Interview techniques & Parent involvement & $\begin{array}{l}\text { Location of the } \\
\text { interview }\end{array}$ \\
\hline 1 & $\begin{array}{l}\text { 'Standard' semi-structured questions, } \\
\text { use of play and use of a hand-- } \\
\text { puppet }\end{array}$ & $\begin{array}{l}\text { Mother and father present, limited } \\
\text { involvement in the conversation }\end{array}$ & At home \\
\hline 2 & $\begin{array}{l}\text { 'Standard' semi-structured questions } \\
\text { and use of Talking Mats@ picture } \\
\text { symbols }\end{array}$ & $\begin{array}{l}\text { Mother present and involved in } \\
\text { making communication easier }\end{array}$ & At home \\
\hline 3 & $\begin{array}{l}\text { Closed questions based on } \\
\text { information from the mother on } \\
\text { which activities the child } \\
\text { performed }\end{array}$ & $\begin{array}{l}\text { Mother present and involved in } \\
\text { interpreting communication } \\
\text { (only non-verbal) }\end{array}$ & At home \\
\hline 4 & 'Standard' semi-structured questions & Mother present but not involved & At home \\
\hline 5 & 'Standard' semi-structured questions & $\begin{array}{l}\text { Mother and father present and } \\
\text { involved in facilitating } \\
\text { communication }\end{array}$ & At home \\
\hline 6 & $\begin{array}{l}\text { 'Standard' semi-structured questions } \\
\text { and use of Talking Mats } ® \text { picture } \\
\text { symbols }\end{array}$ & $\begin{array}{l}\text { Mother and father present, limited } \\
\text { involvement in the conversation }\end{array}$ & At home \\
\hline 7 & $\begin{array}{l}\text { Auto-driven photo elicitation and use } \\
\text { of Talking Mats }{ }^{\circledR} \text { picture symbols }\end{array}$ & $\begin{array}{l}\text { Mother and father present and } \\
\text { involved in the conversation }\end{array}$ & At the hospital \\
\hline 8 & $\begin{array}{l}\text { Use of Talking Mats }{ }^{\circledR} \text { picture } \\
\text { symbols }\end{array}$ & $\begin{array}{l}\text { Mother present and involved in the } \\
\text { communication }\end{array}$ & At home \\
\hline 9 & 'Standard' semi-structured questions & Parents not present & At home \\
\hline
\end{tabular}

Note: interviews for cases 3 and 6 were not analysed further

For the first question, which focused on the type of activities the children perform, thematic coding was used (Miles et al. 2013), because this directed content analysis was appropriate given the previous literature about the topic (Hsieh and Shannon 2005). Predetermined codes based on previous research (Lindenschot et al. 2018) were: activities related to self-care, house chores, therapy, school, computing, hobbies, playing, sports and mobility/transport. Coding was independently performed by two researchers (ML \& JZ) for the first five interviews, which included the Dutch-German interview (JZ is bilingual). These interviews and codes were discussed between the researchers to reach a consensus. If necessary, codes were added or merged. Subsequently, one researcher (ML) coded the remaining interviews. After the thematic coding process, the codes were ordered into pattern codes by ML, and this action led to a network display of the data (Miles et al. 2013). Finally, the themes and quotations were translated into English by the authors, who are qualified at upper-intermediate and advanced English levels, and the quotations and themes were checked by a translation service.

For the other questions that focused on the means of performance, the experience of the activity and the child's wants and needs, no literature existed. Therefore, a conventional content analysis was performed (Hsieh and Shannon 2005) that consisted of three cycles (Miles et al. 2013): 
1. In the first cycle, the transcriptions were coded with open-coding and causation-coding techniques. The first five interviews were independently coded by two researchers (ML and JZ) and then discussed to reach a consensus and form the coding book. Subsequently, one researcher (ML) coded the remaining interviews.

2. The second cycle consisted of forming the codes of the first cycle into pattern codes, an action that led to a narrative description of the data with the use of themes. For the question about means of performing, this cycle was performed by one researcher (ML) because this information was 'factual'. The two other questions (on the experience and the wants and needs) contained more in-depth information; therefore, a nominal group technique (Foth et al. 2016), a more robust analysis method, was chosen. The group consisted of five experts within the allied health care (ML, RN, ES, EC and $\mathrm{SE}$ ), and the analysis was guided by an independent chair (SK). The experts performed the analysis in two independent groups and reached a consensus after explaining their outcomes.

3. The third cycle consisted of forming pattern codes that transcended the three questions; this process led to a network display of the data. This cycle was performed by two researchers (ML and ES) and the entire research group commented on the results to reach consensus. During coding, analytic memos were written to support reliability.

\section{Results}

The children's perspectives on everyday activities is presented in two parts: first, the type of activities, and second, the way (means) of performance, experience and wants/ needs. Due to variability among the children, the themes were present in all interviews, although there was variation in categories.

\section{Types of Activities}

The types of activities the children performed were organised by the three occupational performance areas of Reed and Sanderson (1999): personal maintenance, productivity and leisure. According to Reed and Sanderson (1999), personal-maintenance activities permit a person to maintain individual life-support needs. Productivity activities assist society to facilitate each person to meet individual needs through the use of collective resources. Leisure activities permit the individual to express needs for a creative outlet. Figure 1 presents an overview of the areas, categories and activities; the blue boxes represent the outcomes of the interviews.

Using the framework of Reed and Sanderson (1999), two categories, namely mobility/transport activities and therapy activities, were organised between two occupational performance areas. Therapy activities were performed for the purposes of productivity and personal maintenance, whereas mobility/transport activities were performed as leisure and personal maintenance. This difference in meaning in activity is demonstrated in the following quotes: 
Boy (school age): "I have a special bike. With two wheels at the back and a basket to carry all the groceries when I go shopping with mom or dad. (...). I also cycle to school on it."

Boy (school age): "I love riding my bike, just riding around for fun."

In school activities, children mentioned activities in which they learn by playing. Children did not experience this as a class, but rather as playing, e.g., working on the computer, drawing or painting.

\section{Interviewer: "And do you like colouring?" \\ Boy (school age): "At school!" \\ Interviewer: "Do you like doing that?" \\ Boy (school age): "Yes, fun... I like green...It's nice"}

The difference between the play/game/hobby activities and sports activities was based on how the activities were organised. Some children performed activities in an organised manner, such as part of a soccer or swimming club; these were categorised among the sports activities. When children performed unorganised activities they were categorised within the play/game/hobby activities.

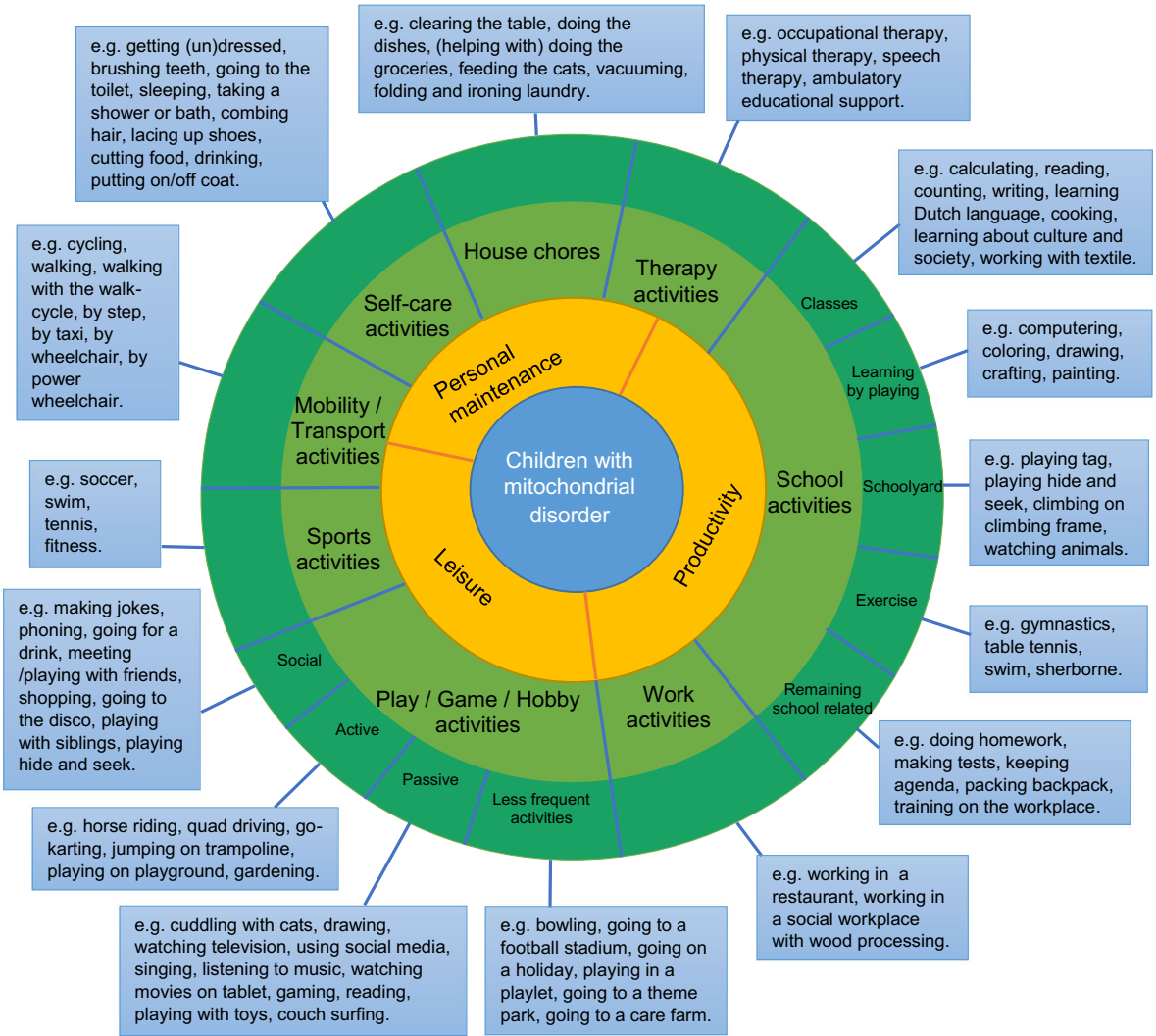

Fig. 1 Occupational performance areas, activity categories and activities of children with a mitochondrial disorder 
All children expressed self-care, mobility/transport and play/game/hobby activities. Six out of the seven children mentioned school and sports activities. The boy that did not express school activities had finished his schooling and was transitioning into the workforce. The child that did not mention sports activities did participate in play/game/hobby activities, but they were all related to school or part of unorganised play/game/hobby activities. House chores were mentioned by four children across the three profiles. Therapy activities were mostly mentioned by parents who were present at the interviews. They mentioned these activities in three out of five cases from the global low functioning profile and the global moderate functioning profile. Work activities were only mentioned by the two children who were old enough to work, as the minimum age for employment in the Netherlands is 15 years.

\section{Wants and Needs, Experience and Performance}

During the interviews and analysis, the three questions on the wants and needs, the experience and the performance were ultimately connected to each other. Therefore, we decided to present the outcomes together. Figure 2 presents the network display that visualises the children's perspective on activities. There were four themes on want/needs: (1) I want to meet up with others whenever I want to, (2) I want to be able to..., (3) I do not want to... and (4) Dream. As these themes on wants/needs are overarching, they were used as the starting point. The themes on experience and performance can be viewed as sub-themes. Themes on experience were: (1) Because I can decide by myself, (2) It is more fun to do things with other people, (3) I just like it, (4) Because I can do it on my own, (5) How I feel about being helped and (6) The things that happen when I am doing the activity make it worthwhile or unpleasant. Themes on performance were: (1) With other people, (2) Adaptation of the physical context, (3) Adaptation of the activity, (4) Regular performance, (5) Support in the social context, (6) Disabilities obstruct performance which can give rise to personal challenges and (7) Performance versus

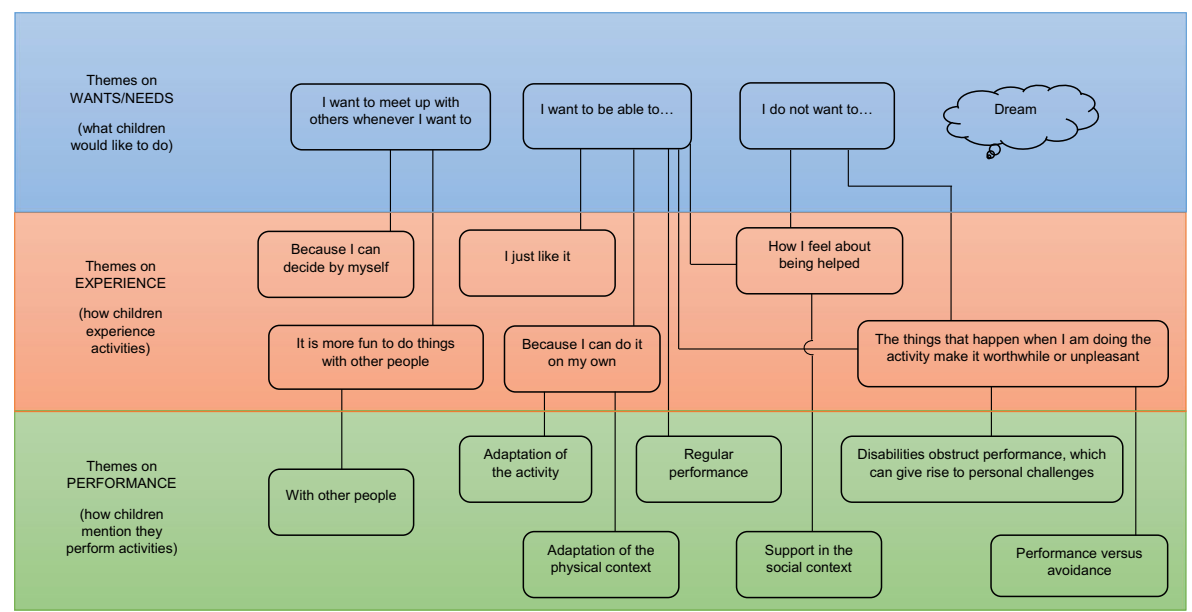

Fig. 2 Network display: visualisation of the children's perspectives on activities 
avoidance. Subsequently, the themes of the different questions are each given their own heading: wants/needs (above the text), experience (in line with text) or performances.

\section{Want to Meet up with Others whenever I Want to}

The children mentioned that they wanted to move around the way they wanted at the time they wanted. This desire held a true connection with meeting others. They wanted to be able to go see friends whenever they wanted to, instead of waiting for parental consent or support to get there.

Boy (school age): "I want to meet up with friends whenever I want to. But my mother then says I cannot meet up with friends because I have to go to hospital. That is stupid."

Girl (adolescent): "I want to go round to my friends whenever I feel like it, even in the evening when it is dark. But I cannot go by myself because it is dark and I cannot see. But I just want to be able to go without someone having to take me there."

In this wants/needs theme, two important subthemes of experience can be recognised: 'Because I can decide by myself' and 'it is more fun to do things with other people'. It also links to one subtheme of performance: 'With other people'.

Because I Can Decide by myself Some children mentioned that the fun part of the activity is that they can decide by themselves when and/or how to do it.

Girl (school age): "I like colouring because you can do it the way you want. I can choose my own colours and make it very pretty."

Boy (school age): "Sometimes I like doing my homework, but sometimes I do not feel like it. It is only fun if I can decide when to do it, so when I feel like it."

It Is More Fun to Do Things with Other People Children also mentioned that most fun activities were even more pleasant when you do them with other people. Further, several activities were only fun when you did them with other people.

Boy (school age): "My favorite activities are bowling, going to the movies and taking a bath. And they are even more fun with other people."

Some children also noted that it should be with the 'right' people, i.e., the people they prefer.

With Other People Regarding the performance of activities, children regularly mentioned that they performed activities with other people, namely friends, parents, siblings and other family members.

Girl (school age): "I love playing with my sister. I love it when she jumps on the trampoline while I am sitting on it. Then I go up high in the air. It really 
makes me laugh. And also when I am in my wheelchair and she is skating behind me. I want to do that now. Mom, can I do that now?"

One child mentioned that he preferred to play with adults instead of children.

Boy (school age):" I would really like to go to a theme park."

Interviewer: "Who would you like to go with?"

Boy (school age): "My family (...), my uncle, my aunt and E. and I."

Interviewer: Are they your cousins?

Boy (school age): "No, they are adults. I prefer going with adults. Not with children. I also prefer playing with adults."

Although there were also activities they performed alone, the children mostly liked to play with other people.

Boy (adolescent): "I like playing on my PlayStation."

Interviewer: "Who do you play with?"

Boy (adolescent): "My brother, my friends or just by myself."

Interviewer: "Which do you like best?"

Boy (adolescent): "Playing with my friends or brother is the best."

\section{Want to Be Able to}

Children wanted to be able to learn things, do things better longer, (more) independently and/or just like others. With 'things', different aspects were mentioned. Sometimes, children talked about specific functions (e.g., being able to stand longer), skills (e.g., learning to dive like a dolphin), tasks (e.g., being able to select a cartoon movie on the computer) or activities (e.g., learning to play a musical instrument or being able to play soccer).

Boy (school age): "I want to do a nose manual on my BMX bike. My friends can already do that, but I cannot yet. I can do it on the back wheel, a little bit. But not on the front wheel."

This wants/needs group was related to four themes that children stated in their experience of activities. Two of these themes were solely related to 'being able to': children experienced the activities positively when they were able to do it on their own or just because it was fun. The other two themes, related to 'I do not want to...', will be presented in the upcoming section.

I Just like it Some activities that children were able to do were 'just fun' for children. They did not have a specific reason for it; they just experienced it as fun.

Boy (school age): "I like taking a bath."

Interviewer: "Why do you like that?" 
Boy (school age): “Just.... It is just fun.”

Because I can do it on my own Activities were experienced positively when children were able to do them on their own.

Girl (school age): "I like getting dressed... I really like doing this."

Interviewer: "Why do you like it so much?"

Girl (school age): "Because... Because I can do it on my own. I am six years, that is a lot. I like it when

I can do things on my own."

'Doing it on your own' linked to the performance themes 'adaptation of the physical context' and 'adaptation of the activity'. The adaptation was accepted because it enabled the child to execute activity. When adaptation did not lead to independence, it was harder for the child to accept. For instance, one child who was advised to use a blind guide stick did not want to do that because it would be used as a signal for others to provide help, instead of making walking outside easier.

Girl (adolescent): "I went to another school because I was being bullied. I could not see very well either, so I had a white cane, but I never used it."

Interviewer: "Why were you bullied?"

Girl (adolescent): 'I do not know."

Interviewer: "Did it have anything to do with your sight problems or your white cane?

Girl (adolescent): "I never used the white cane.. I did not want other people to see it and think that I cannot do anything or need help. And I could not go out in the dark with it, that was always difficult. I think I got bullied because some people were making trouble for me."

Adaptation of the Physical Context Children noted physical adaptations, for instance, the use of 'regular' objects to make the activity easier.

Girl (adolescent): "I get tired when I have a shower, and sometimes I get dizzy too. Then I just sit down on the stool and rest for a minute.

Additionally, aids or assistive devices were used, such as a blind guide stick, a slide for bowling or a recumbent bike. In some cases, toys were adapted to make them suitable for their capabilities.

Interviewer: "Why is there sticky tape on the cupboards of your play-kitchen?

Girl (school age): "So I can open them." 
Adaptation of the Activity Besides the physical and social context, the activity was also adjusted by the children or their parents. In some cases, children decided the adjustment themselves; one child mentioned that she just cycles a bit more slowly when she gets tired. Additionally, children sometimes requested adjustments themselves, as demonstrated in the following quotation:

Boy (school age): "Sometimes I feel sad because I cannot run as fast as my friends. (...) They run very fast when we play tag."

Interviewer: "Do you do that in your wheelchair, or do you run?"

Boy (school age): "I run, like my friends. But not as fast. I can run fast, but they... they go faster. Sometimes I ask them to slow down a bit. And then I try not to get tagged."

Interviewer: "And how does that go?"

Boy (school age): "It is all right. Otherwise I use a bike, so I do not have to run."

Occasionally, parents or professionals arranged activity adaptations, such as adjustments to exam rules for a swimming degree or rest moments during the activity.

Regular Performance In the theme 'I want to be able to...', children also mentioned they performed several activities in the same way as their peers, a phenomenon we refer to as 'regular performance'. Sometimes, this act meant that the children received support when performing these activities, but this support was age appropriate and therefore not experienced as support.

Girl (school age): "I brush my teeth every morning and evening."

Interviewer: "Do you do that all on your own?"

Girl (school age): "Yes! (...) Well, mom and dad help me sometimes."

Interviewer: "What do mum and dad do when they help?"

Girl (school age): "They 'after-brush' my teeth."

Interviewer: "Do they think you didn't do it properly?"

Girl (school age): "Sometimes I skip a bit, that is why they do it."

\section{Do Not Want to}

The children were also outspoken about things they did not want. They did not want to experience discomfort caused by their disorder; for instance, they did not want to get tired or feel muscle pain. Also, some children did not want to use aids, because this use made them feel disabled.

Girl (adolescent): "If I have to walk very far, I should really use a wheelchair. But I do not want to. It makes me feel like there is something wrong with me. And I do not want to feel like that."

In contrast, some children also said they were satisfied with the way things were. They did not want change, nor did they want to be able to do things better, even though their peers were better at performing the activity. 
Boy (school age): "I do not like playing soccer at school. I am not very good at it and the ball is

too hard. But I do not mind. It is fine the way it is. I only play it at home with friends now. With a soft ball."

This wants/needs theme related with two experiences, both of which were also related to the theme 'I want to be able to': 'how I feel about being helped' and 'things that happen when I am doing the activity make it worthwhile or unpleasant'. In both experiences, this feeling could lead to the child wanting to be able to perform the activity or not wanting something.

How I Feel about Being Helped Children experienced receiving assistance differently: it even varied by activity for each individual. There were many situations in which children did not mind getting help, and they noted that getting help could be nice because it would make performing the activity easier. In other situations, children did not like to ask for help. They wanted to be able to do it on their own. The following quotations demonstrate the complexity and differences between experiences in being helped:

Boy (school age): "I do not like showering because someone has to help me. I want to do it by myself, but dad always wants to help me."

Girl (adolescent): "I need help cutting up my food when we go out for a meal. I still order meat and ask someone else to cut it up for me. But I do not like asking for help. I want to be able to do it on my own."

Boy (school age): "I do not mind that mum and dad helping me go to the bathroom. That is just the way it is."

Support was provided by the social context. Children mentioned several sources of social support.

Support in the Social Context The support that children received could be professional or from peers, family or teachers.

Boy (school age): "I watch television."

Interviewer: "And who switches the television on?"

Boy (school age): "I do! Sister helps."

Interviewer: "What does your sister do?"

Mother: "He can switch the television on, but his sister switches the TV to the right channel."

Boy (school age): "I switch it off."

The support varied from a little help to fully taking over the activity. Mostly, activities were taken over by parents and mainly comprised self-care activities, including getting dressed, combing hair, tying laces or brushing teeth.

The Things that Happen when I Am Doing the Activity Make it Worthwhile or Unpleasant With 'things that happen', children mentioned factors in the process of performing the activity and the results or consequences of the execution. 
Either factor could make the activity fun or unpleasant. Sometimes, just performing the activity made it fun, like playing. There was no goal with the play: playing made the activity attractive. Children also noted that variety made the activity pleasant.

Girl (school age): "I like yoga (...) we do it at school with a different teacher than the one we have all day (...) It is fun because it is always a bit different."

In other situations, the results or consequences of the activity made it worthwhile to perform, for instance, earning money by working or being able to play with Legos when they finished building.

Boy (adolescent): "What I like about going shopping? Learning how to handle money, that is important for when I am older. You see, I will have to move out at some point, so I will need to know how much money I will need to buy something big or whatever."

The same difference was also negatively mentioned by the children; the process of performing the activity could make it unattractive, such as needing to practice stepping before getting good at it or because they got tired of the performance. The consequences could also be experienced negatively. For example, children felt that the activity restricted them from being able to play.

Girl (school age): "I do not like combing my hair (...) Because then I cannot go and play then, and I want to play all the time."

How the children experienced the activity was influenced by their disabilities, which could rise to personal challenges and therefore, could lead to either performing or avoiding the activity.

Disabilities Obstruct Performance, which Can Give Rise to Personal Challenges When asked about the way they performed activities, the children mentioned motor or cognitive disabilities that obstructed their performance.

Girl (adolescent): "I like drawing, but I cannot concentrate for very long. Only for about half an hour and then I get distracted again... That is frustrating." Girl (school age): "I do not like walking (...) I get so tired when I walk, I do not want to do that all the time."

In some cases, disabilities resulted in personal struggles or challenges.

Girl (adolescent): "Next week we are going to a theme park (...) Then we will have to walk a lot. I do not know if I will be able to keep up (...) Actually, I do not think I will be able to walk for that long."

Interviewer: "Have you ever had to walk that much before?" 
Girl (adolescent): "Yes, when I go shopping with my mom or my friends (...) I always get very tired at some point. Then all I want to do is sit down, and I cannot stand up any more. Then I get very tired and my legs start to give way."

Interviewer: "And what do you do in that situation?"

Girl (adolescent): "I do not know (...) I do not want to be in a wheelchair because it makes me look stupid (...) like there is something wrong with me (...)"

Interviewer: "But what do you do when you are very tired?"

Girl (adolescent): "I do not know."

Performance Versus Avoidance In some situations, children did not (want to) perform an activity due to their disabilities and the experience when they performed the activity. A mother mentioned that her child avoided activities that were too tiring or difficult for her, such as cycling or crafting. Children also mentioned that they did not perform activities that were too difficult or not allowed due to their disabilities.

Interviewer: "Are there things you cannot do that you would like to be able to do?"

Boy (adolescent): "Drive a car, I cannot do that at all, I am not allowed to take my driving test."

Interviewer: "Not at all?"

Mother: "No, he is only allowed to drive at $6 \mathrm{~km} / \mathrm{h}$, so that is the electric wheelchair. The problem is that he..., multitasking is very difficult for him. If he has to do two things at once. He cannot even ride a bike because of his balance. At least not a normal one. He can ride a three-wheeler, but not a twowheeler. No, that is just too dangerous. He cannot ride a two-wheeler anyway because of his balance. He can manage a three-wheeler, but he cannot watch out for the traffic yet. He has had three, four situations with a bike... they were really..."

Boy (adolescent): "The last one was the one with the suitcase when I took the bend too tightly on the three-wheeler. I got a nosebleed too."

\section{Dream}

Children also spoke about their dreams. This theme was not connected to themes of experience or current performance but rather encompassed several things the children would like. The dreams consisted of fantasies (e.g., travelling around the world in a rocket ship or becoming a Power Ranger), future plans (e.g., becoming a professional chef or living on their own), wishes for their appearance (e.g., having bigger breasts or gaining weight) or objects they would like to get (e.g., a scooter or Legos).

Girl (adolescent): "I would really like to start doing a new sport. I think I would like to do kickboxing. Just having a good old punch and getting rid of some anger. I think I will do that after the summer break." 


\section{Discussion}

This study is the first that focused on the perspectives of children with multiple disabilities on everyday activities. Children with a mitochondrial disorder were given a voice, and they engaged the researchers in a rich variety of topics that reflected their broad perspective on performing activities. The activity categories identified in this population are in line with the previously conducted chart review (Lindenschot et al. 2018) and consist of regular childhood enterprises. Additionally, the current findings revealed that some children with a mitochondrial disorder performed activities just like their peers, while others required adaptations that depended on the activity. The broad perspective children gave was divided into three factors: wants and needs, experiences and the way (means) of performance. One of the key themes was that children expressed they wanted to meet up with others whenever they wanted to. The experience of deciding by themselves was important. Besides, children mentioned that performing activities with other people was more fun than doing them by themselves. A second key theme was that children wanted to be able to learn things, do things better/longer/ (more) independently or "as others". Several factors would make them want to perform the activity: because they just liked it, they could do it on their own and the things that happened when they performed the activity made it worthwhile. Some performed the activities in a regular way (just as peers), but if necessary, physical and/or social adaptations supported the performance. As a third key theme, children expressed things they do not want, like experiencing discomfort caused by their disorder. Their disability could cause personal challenges that could result in avoiding the activity. The fourth and final key theme was that children expressed dreams about their future plans, wishes for their appearance, objects they would like to get and their fantasies. These findings can be used in daily practice because they provide greater understanding of the children's experiences and motivations to participate in everyday activities.

The wants and needs and experiences of the interviewed children can be related to the self-determination theory (SDT). This theory proposes that people perform activities to fulfil three basic psychological needs: autonomy, competence and relatedness (Deci and Ryan 2000, 2008). Autonomy refers to volition through self-organised experiences that are consistent with a sense of self (Deci and Ryan 2000) and fits with the theme 'I want to meet up with others whenever I want to' and 'I do not want to'. For example, it is clear that the children wanted to feel autonomous when they expressed their experience as 'Because I can decide by myself'. Competence is believing that one can efficaciously interact with human and non-human environments, and it was apparent in the theme 'I want to be able to', with, for example, the sub-theme 'Because I can do it on my own'. Additionally, the theme 'How I feel about being helped' showed that support was accepted when it supported competence. This finding fits with the SDT that states competence is one of the factors that enhances intrinsic motivation (Poulsen et al. 2006; Ryan and Deci 2000; Deci and Ryan 2008). Relatedness refers to the presence of support, warmth and affection through connections with others (Deci and Ryan 2000). It links to the theme 'I want to meet up with others whenever I want to' and, for example, the subtheme 'It is more fun to do things with other people'. Although the theme 'Dream' does not have an obvious link to autonomy, competence or relatedness, it can still relate to the way it influences the intrinsic motivation of the child to work towards her/his dreams and goals. Therefore, the SDT and the children's 
perspectives identified in this research help us understand the deeper meaning of why children choose to perform or avoid certain activities.

Knowledge about the motivation to perform or avoid activities can be used by people who are involved in children's everyday lives, including parents, teachers and health professionals. Parents, teachers and children do not mention the same goals for occupational therapy intervention. Costa et al. (2017) compared these goals and showed that whereas parents and teachers are mainly focused on the occupational performance area productivity, children mention goals in all three areas: productivity, personal maintenance and leisure. This finding fits within the large scope of activities performed by children with a mitochondrial disorder, which was already known (Lindenschot et al. 2018) and expanded in the current study. Further, the current findings revealed reasons for performing activities, for example, to have fun with others, experience the ability to do something on their own or because something happens that makes it worthwhile. These reasons were also present in the study of Costa et al. (2017), who state that children choose their goals due to social motives, their independence and the ease, competence and joy they experience when engaging in a certain activity. These reasons can be seen as the values of children, and they can be used in designing treatments, specifically occupational therapies. Occupational therapists use everyday activities to achieve goals, also called occupation as ends, but also as a means for therapeutic power (Duncan 2013; Gray 1998). Actually, this factor comprises part of the unique realm of occupational therapy's expertise (Golledge 1998; Gray 1998). Using occupation as a means refers to the use of therapeutic occupations as the treatment modality to advance someone towards an occupational outcome (Gray 1998). To use occupation as a means, the therapist selects activities related to the client's occupations and interests that can be modified and structured to improve functions or skills relevant for functional goals, which are everyday activities (Gray 1998). Therefore, the current findings can be utilised for occupation as means and ends. Although therapeutic power of everyday activities is personalised and based on the values of the individual child, the findings support potential values for which activities can be used as a means. Besides, the findings demonstrate the large scope of potential activities in therapy goals for school functioning. Therefore, the study results are useful for parents, teachers and health professionals to focus on the entire scope of potential relevant activities, and to determine the values in activities. Moreover, the results can especially be used by occupational therapists to use occupation as a means or as ends.

Activities were divided into eight activity categories (self-care, house chores, therapy, school, work, play/game/hobby, sports and mobility/transport) and three occupational performance areas (personal maintenance, productivity, and leisure; (Reed and Sanderson 1999). Although there are some criticisms concerning the use of three occupational performance areas (Hammell 2009), the findings provided a good overview of the activities performed by this group of children. As suggested by Hammell (2009), we could use an occupational experience-based categorisation. However, experience is very much individually determined (Wilcock 2006), a phenomenon confirmed by the children's perspectives in this study. Therefore, distinguishing the type of activities and the experiences of the child has added value. Additionally, the Person-Environment-Occupation-Performance (PEOP)-model interaction perspective provides another perspective on the findings. When used within occupational therapy, this model defines the level of participation as the result of an interaction between person, occupations and environment (Baum et al. 2015). This interaction was clearly 
present in what the children expressed about their way (means) of performing activities. They could participate due to adaptations of the activity or physical context. Further, it was clear from their stories that in the interactions among persons, occupations and environment there were personal challenges that could lead them to avoid doing the activity. Therefore, the PEOP model can be useful in practice when collecting information about occupational performance from the child's perspective.

The transferability of the child's perspective is influenced by the study population. Children with mitochondrial disorders represent various limitations that are also present in several other groups, e.g., children with physical disabilities, neurological impairments, developmental disabilities or intellectual disabilities. The same themes probably exist in these populations, although the exact experiences will differ. For example, Powrie et al. (2015) found that for children with physical disabilities, fun, freedom, fulfilment and friendship are important for leisure. They also connect their results to the SDT. Another review that related their findings to the SDT included children with various disabilities (Willis et al. 2017). They found three categories, namely personbased elements (having fun, experiencing success, belonging, experiencing freedom and developing an identity), environment-focused elements (authentic friendships, the opportunity to participate, role models and family support) and activity-related elements (learning), that contribute to meaningful participation. 'Having fun' and 'family support' were also apparent from our interviews. Other elements were not exactly the same but contained similarities in the descriptions of the elements/themes. For example, 'experiencing success' shows similarities to our themes 'Because I can do it on my own' and 'The things that happen when I am doing the activity make it worthwhile (or unpleasant)'. The latter theme was also in line with the themes 'experiencing freedom' and 'learning'. 'Having an identity' has no connection with our findings. However, an explanation could be that Willis et al. (2017) studied meaningful participation, while the current study focused on how children value everyday activities. Moreover, the element 'having identity' emerged based on data from the children's and parents' perspective, whereas our themes are solely based on the children's perspectives. We feel that the results are transferable. The outcomes are comparable to other literature, and children with a mitochondrial disorder represent a wide spectrum of disabilities, and thus they may considered representative of other children with mild-to-severe physical and developmental disabilities.

The transferability of the child's perspective was also influenced by the age range (218 years) in the sample. This relatively wide range is possible because the different aspects of participation are the same for all age groups (Eriksson and Granlund 2004). In this study, the youngest child was 6 and the oldest was 18. We found the same themes in all age groups; however, there were some differences in the way they were expressed. These disparities are consistent with the theory of Erikson (1993). The theme 'Dream' especially highlights these expression differences. While the dreams of school-aged children focused more on fantasy and objects/materials, adolescent children expressed wishes about their appearance and future plans. These differences fit with Erikson's fifth stage-identity versus role confusion - in which adolescents search for a sense of self and personal identity and begin to look at the future. In the theme 'I want to meet up with others whenever I want to', there was a shift from being able to choose to self-govern. Besides the consistency with the theory of Erikson (1993), this shift is also in line with Eriksson and Granlund (2004), who describe the same alteration and mention that the SDT is recognisable in all age groups. Specifying 
the differences between the age groups would require a larger sample. However, the results of this study provide a good overview of the 6-18-year-old age group in this heterogeneous sample of children with a mitochondrial disorder.

The heterogeneity of developmental disabilities in our population required flexible and tailor-made interview techniques. Techniques were adapted based on the child's cognitive development (Piaget 1964), communication abilities and preferences. Whereas play and hand-puppets were used with a 6-year-old child with lower developmental abilities (global low functioning), auto-driven photo elicitation was used with a 6-year-old child with higher developmental abilities (global moderate functioning). The results appear trustworthy, because feedback from parents resulted in the addition of only two activities in total to all interviews. As mentioned, an in-depth description of the methods used is presented in Steultjens et al. (submitted). They analyse the utilised interview techniques for the nine interviewed children and conclude that the tailor-made interview techniques successfully gain the child perspective for the children included in the current study. The standard semistructured interview would not have led to this success, nor was one technique applicable to all children. Therefore, to be able to give children with developmental disabilities and restricted communication a voice, and thus to include their perspective in research, tailormade interview techniques are necessary.

A limitation of this study could be that only seven children participated. Still, several procedures were performed to enhance the quality and trustworthiness of this research. Attention was paid to the standards for reporting qualitative research (O'Brien et al. 2014) and criteria to strengthen rigour (Kitto et al. 2008). The interview method was piloted and further developed with health care professionals, parents and children before being used in this research. The utilised interview techniques enhanced the ability to capture the children's perspectives, a factor that was more important than having a larger sample. The decision-algorithm of the interview techniques could be more systematic. However, because this was the first qualitative in-depth interview with this population (which included communicatively vulnerable people), we decided to develop the decision-algorithm while conducting the research. To ensure procedural rigour and gain knowledge on interview techniques with communicatively vulnerable people, the utilised techniques and their effects on the children were analysed and will be published separately (Steultjens et al. submitted). Despite the interview method variations, two of the nine children were not able to express their perspectives. To ensure interpretative rigour, these two interviews were not analysed, because the aim of this research was to capture the child's perspective. Still, the variations in this population represented children with mitochondrial disorders, and the sample size was large enough to determine specific themes. However, inclusion of more children might have increased nuance within the themes. In addition to the procedural rigour (dependability), two researchers coded the data independently from each other, and the variations between the researchers were discussed if necessary to reach a consensus on the coding procedure. A nominal group technique was used to form themes. Another point about procedural rigour is the Dutch-German interview. The researcher is a native Dutch with intermediate competence in German. Thus, she can understand the main points of clear standard input and the spoken language. Therefore, the child's answers were not translated by the mother because the researcher could comprehend them. Besides, the researcher noticed when the mother translated her 
question differently than she intended, and she could ask the mother to rephrase or ask the question in German herself. Intermediate understanding of German was not good enough to conduct the entire interview in German. Precautions were taken to preserve the meaning of the original interview: a bilingual person (JZ) transcribed and coded it. The results of all the interviews were translated into English for writing the article; there were no English translation before manuscript preparation in order to preserve meaning of the original interviews. To improve interpretive rigour (credibility), parents were asked to check data on the type of activities, but not for experiences, as we did not want to influence the children's perspective. To enhance confirmability, we did not use the predetermined codes as a fixed set. Consequently, the predetermined codes were not the final codes, because the interviews provided more information and refined the codes. Based on the taken precautions and the broad perspective exposed by this research, we feel that the findings are representative of children with mitochondrial disorders.

The findings can be used to establish occupation-based, value-based and personalised care. A next step would be to develop adequate assessment procedures to capture these meaningful activities (Coster and Khetani 2008). In other words, assessment should be able to capture a variety of activities. Besides, the very individually determined way (means) of performance should be part of the measurement and therefore an assessment also needs to allow customisation of activities. Subsequently, an assessment should be able to measure occupational performance without floor or ceiling effects for the different global functioning profiles (Lindenschot et al. 2018). The findings of the current study can be used to develop assessments for children with mitochondrial disorders to enhance personalised and value-based care.

\section{Conclusion}

This qualitative study exposed the perspectives and values of children with a mitochondrial disorder on their everyday activities. Children expressed their perspective on their wants and needs, how they experienced activities and how they performed the activities. These three factors were interconnected. The identified themes fit with the SDT, which was developed for children of all ages and different developmental abilities, and proposes that people perform activities to fulfil three basic psychological needs: autonomy, competence, and relatedness. The important aspects were meeting up with others whenever they wanted to, being able to learn things, do things better, longer, (more) independently or just like others, not performing activities that caused discomfort and dreams. The themes showed person-based, activity-based, contextbased and participation-based elements. This study shows how children with mitochondrial disorder experience and value everyday activities. It contributes to understanding of choices of children with disabilities and the stimulation their motivation in participating in everyday activities, information that is relevant for parents, teachers and health care professionals. For example, occupational therapists can use the findings to consider the entire scope of valued activities, dreams and experiences to use occupation as ends and occupation as means. Furthermore, the study provides a foundation for selecting and developing assessments to measure activity performance that can 
contribute to personalised and value-based care, which puts emphasis on involving the children's perspective in care.

Acknowledgments We would like to thank the children and parents who participated in this study. Also, we would like to thank Edith Cup, $\mathrm{PhD}$ and Sabine van Erp, MSc for participating in the nominal group technique analysis. Lastly, we would like to thank Christel Brink for drawing additional Talking Mats cards.

Funding This work was supported by the Netherlands Organization for Scientific Research (NWO) [project number 023.009.016].

\section{Compliance with Ethical Standards}

\section{Conflict of Interest None.}

Ethical Approval The ethical board of the regional research committee provided their consent in undertaking this research (ethical board approval number 2016-2968). Data were analysed anonymously. The research was conducted in accordance with the ethical principles of the Declaration of Helsinki (General Assembly of the World Medical 2014). Therefore, all procedures performed in studies involving human participants were in accordance with the ethical standards of the institutional and/or national research committee and with the 1964 Helsinki declaration and its later amendments or comparable ethical standards.

Informed Consent All parents signed informed consent. If possible, the children also signed the informed consent to recognise their volition/agency (Stafford et al. 2003).

Open Access This article is distributed under the terms of the Creative Commons Attribution 4.0 International License (http://creativecommons.org/licenses/by/4.0/), which permits unrestricted use, distribution, and reproduction in any medium, provided you give appropriate credit to the original author(s) and the source, provide a link to the Creative Commons license, and indicate if changes were made.

\section{References}

Asbjornslett, M., \& Hemmingsson, H. (2008). Participation at school as experienced by teenagers with physical disabilities. Scandinavian Journal of Occupational Therapy, 15(3), 153-161. https://doi. org/10.1080/11038120802022045.

Baum, C., Christiansen, C., \& Bass, J. (2015). The Person-Environment-Occupation-Performance (PEOP) Model. In C. B. Christiansen, C., and Bass-Haugen, J. (Ed.), Occupational Therapy: Performance, Participation and Well-Being. . Thorofare, NJ: Slack.

Bendixen, R. M., \& Kreider, C. M. (2011). Review of occupational therapy research in the practice area of children and youth. American Journal of Occupational Therapy, 65(3), 351-359. https://doi.org/10.5014 /ajot.2011.000976.

Costa, U. M., Brauchle, G., \& Kennedy-Behr, A. (2017). Collaborative goal setting with and for children as part of therapeutic intervention. Disability and Rehabilitation, 39(16), 1589-1600.

Coster, W., \& Khetani, M. A. (2008). Measuring participation of children with disabilities: Issues and challenges. Disability and Rehabilitation, 30(8), 639-648. https://doi.org/10.1080/09638280701400375.

Coyne, I., Hallstrom, I., \& Soderback, M. (2016). Reframing the focus from a family-centred to a childcentred care approach for children's healthcare. Journal of child health care : for professionals working with children in the hospital and community. https://doi.org/10.1177/1367493516642744.

Dassler, A., \& Allen, P. J. (2014). Mitochondrial disease in children and adolescents. Pediatric Nursing, 40(3), 150 . 
de Vries, P. R., Janssen, M., Spaans, E., de Groot, I., Janssen, A., Smeitink, J., et al. (2019). Natural variability of daily physical activity measured by accelerometry in children with a mitochondrial disease. Mitochondrion, 47, 30-37.

Deci, E. L., \& Ryan, R. M. (2000). The" what" and" why" of goal pursuits: Human needs and the selfdetermination of behavior. Psychological Inquiry, 11(4), 227-268.

Deci, E. L., \& Ryan, R. M. (2008). Self-determination theory: A macrotheory of human motivation, development, and health. Canadian Psychology/Psychologie Canadienne, 49(3), 182.

Duncan, E. A. (2013). Foundations for practice in occupational therapy (fifth ed.). London: Elsevier Health Sciences.

Erikson, E. H. (1993). Childhood and society: WW Norton \& Company.

Eriksson, L., \& Granlund, M. (2004). Conceptions of participation in students with disabilities and persons in their close environment. Journal of Developmental and Physical Disabilities, 16(3), 229-245.

Foth, T., Efstathiou, N., Vanderspank-Wright, B., Ufholz, L.-A., Dütthorn, N., Zimansky, M., et al. (2016). The use of Delphi and nominal group technique in nursing education: A review. International Journal of Nursing Studies, 60, 112-120.

General Assembly of the World Medical, A. (2014). World medical association declaration of Helsinki: Ethical principles for medical research involving human subjects. The Journal of the American College of Dentists, 81(3), 14-18.

Golledge, J. (1998). Distinguishing between occupation, purposeful activity and activity, part 2: Why is the distinction important? British Journal of Occupational Therapy, 61(4), 157-160.

Gorman, G. S., Schaefer, A. M., Ng, Y., Gomez, N., Blakely, E. L., Alston, C. L., et al. (2015). Prevalence of nuclear and mitochondrial DNA mutations related to adult mitochondrial disease. Annals of Neurology, 77(5), 753-759.

Graham, N., Nye, C., Mandy, A., Clarke, C., \& Morriss-Roberts, C. (2018). The meaning of play for children and young people with physical disabilities: A systematic thematic synthesis. Child: Care, Health and Development, 44(2), 173-182. https://doi.org/10.1111/cch.12509.

Gray, J. M. (1998). Putting occupation into practice: Occupation as ends, occupation as means. American Journal of Occupational Therapy, 52(5), 354-364.

Hammell, K. W. (2009). Self-care, productivity, and leisure, or dimensions of occupational experience? Rethinking occupational "categories". Canadian Journal of Occupational Therapy, 76(2), 107-114.

Heah, T., Case, T., McGuire, B., \& Law, M. (2007). Successful participation: The lived experience among children with disabilities. Canadian journal of occupational therapy. Revue canadienne d'ergotherapie, 74(1), 38-47. https://doi.org/10.2182/cjot.06.10.

Hsieh, H. F., \& Shannon, S. E. (2005). Three approaches to qualitative content analysis. Qualitative Health Research, 15(9), 1277-1288. https://doi.org/10.1177/1049732305276687.

Kisler, J. E., Whittaker, R. G., \& McFarland, R. (2010). Mitochondrial diseases in childhood: A clinical approach to investigation and management. Developmental Medicine \& Child Neurology, 52(5), 422433. https://doi.org/10.1111/j.1469-8749.2009.03605.x.

Kitto, S. C., Chesters, J., \& Grbich, C. (2008). Quality in qualitative research. Medical Journal of Australia, 188(4), 243-246.

Koene, S., \& Smeitink, J. (2009). Mitochondrial medicine: Entering the era of treatment. Journal of Internal Medicine, 265(2), 193-209. https://doi.org/10.1111/j.1365-2796.2008.02058.x.

Koene, S., Wortmann, S. B., de Vries, M. C., Jonckheere, A. I., Morava, E., de Groot, I. J., et al. (2013). Developing outcome measures for pediatric mitochondrial disorders: Which complaints and limitations are most burdensome to patients and their parents? Mitochondrion, 13(1), 15-24. https://doi.org/10.1016 /j.mito.2012.11.002.

Koopman, W. J. H., Willems, P. H. G. M., \& Smeitink, J. A. M. (2012). Monogenic mitochondrial disorders. New England Journal of Medicine, 366(12), 1132-1141. https://doi.org/10.1056/NEJMra1012478.

Law, M., Missiuna, C., Pollock, N., \& Stewart, D. (2005). Foundations for occupational therapy practice with children. In J. Case-Smith (Ed.), Occupational therapy for children (pp. 53-87). St. Louis, Missouri: Elsevier Mosby.

Lindenschot, M., de Groot, I. J., Koene, S., Satink, T., Steultjens, E. M., \& Nijhuis-van der Sanden, M. W. (2018). Everyday Activities for Children with Mitochondrial Disorder: A Retrospective Chart Review. Occupational Therapy International, 2018.

Martens, A. M., Gorter, H., Wassink, R. G., \& Rietman, H. (2014). Physical activity of children with a mitochondrial disease compared to children who are healthy. Pediatric Physical Therapy, 26(1), 19-26. https://doi.org/10.1097/PEP.0000000000000016.

Miles, M. B., Huberman, A. M., \& Saldana, J. (2013). Qualitative data analysis: Sage. 
O’Brien, B. C., Harris, I. B., Beckman, T. J., Reed, D. A., \& Cook, D. A. (2014). Standards for reporting qualitative research: A synthesis of recommendations. Academic Medicine, 89(9), 1245-1251.

Piaget, J. (1964). Part I: Cognitive development in children: Piaget development and learning. Journal of Research in Science Teaching, 2(3), 176-186.

Poulsen, A. A., Rodger, S., \& Ziviani, J. M. (2006). Understanding children's motivation from a selfdetermination theoretical perspective: Implications for practice. Australian Occupational Therapy Journal, 53(2), 78-86. https://doi.org/10.1111/j.1440-1630.2006.00569.x.

Powrie, B., Kolehmainen, N., Turpin, M., Ziviani, J., \& Copley, J. (2015). The meaning of leisure for children and young people with physical disabilities: A systematic evidence synthesis. Developmental Medicine and Child Neurology, 57(11), 993-1010. https://doi.org/10.1111/dmcn.12788.

Rahman, J., \& Rahman, S. (2018). Mitochondrial medicine in the omics era. The Lancet.

Reed, K. L., \& Sanderson, S. N. (1999). Concepts of occupational therapy (Vol. book, whole): Lippincott Williams \& Wilkins.

Ryan, R. M., \& Deci, E. L. (2000). Self-determination theory and the facilitation of intrinsic motivation, social development, and well-being. American Psychologist, 55(1), 68.

Shields, N., King, M., Corbett, M., \& Imms, C. (2014). Is participation among children with intellectual disabilities in outside school activities similar to their typically developing peers? A systematic review. Developmental Neurorehabilitation, 17(1), 64-71. https://doi.org/10.3109/17518423.2013.836256.

Stafford, A., Laybourn, A., Hill, M., \& Walker, M. (2003). 'Having a say': Children and young people talk about consultation. Children \& Society, 17(5), 361-373. https://doi.org/10.1002/CHI.758.

Wilcock, A. A. (2006). An occupational perspective of health (Vol. book, whole): Slack incorporated.

Willis, C., Girdler, S., Thompson, M., Rosenberg, M., Reid, S., \& Elliott, C. (2017). Elements contributing to meaningful participation for children and youth with disabilities: A scoping review. Disability and Rehabilitation, 39(17), 1771-1784. https://doi.org/10.1080/09638288.2016.1207716.

Publisher's Note Springer Nature remains neutral with regard to jurisdictional claims in published maps and institutional affiliations.

\section{Affiliations}

\section{Marieke Lindenschot ${ }^{1,2,3,4}$ • Esther M. J. Steultjens ${ }^{2,3}$ • Jana Zajec ${ }^{4}$ - Maria W. G. Nijhuis-van der Sanden ${ }^{1,4}$. Saskia Koene ${ }^{5}$ Imelda J. M. de Groot ${ }^{4}$}

1 Department of IQ Healthcare, Radboud Institute for Health Sciences, Radboud University Medical Center, Postbus 9101, Nijmegen, GA 6525, The Netherlands

2 Department of Occupational Therapy, HAN University of Applied Sciences, Postbus 6960, Nijmegen, GA 6503, The Netherlands

3 Research Group Neurorehabilitation, HAN University of Applied Sciences, Postbus 6960, Nijmegen GA 6503, The Netherlands

4 Department of Rehabilitation, Donders Center for Neuroscience, Radboud University Medical Center, Postbus 9101, Nijmegen, HB 6500, The Netherlands

5 Department of Pediatrics, Radboud Center for Mitochondrial Medicine, Radboud University Medical Center, Geert Grooteplein Zuid 10, Nijmegen, GA 6525, The Netherlands 